\title{
ANTI-DIABETIC EFFECT OF ETHANOL EXTRACT OF Copaifera salikounda (HECKEL) AGAINST ALLOXAN-INDUCED DIABETES IN RATS
}

\author{
Chinyere Aloke ${ }^{1 *}$, Emmanuel Sunday Igwe $^{1}$, Nwogo Ajuka Obasi ${ }^{1}$, Pascal Anyaegbunam Amu², Egwu Chinedu Ogbonnia ${ }^{1}$ \\ ${ }^{1}$ Department of Medical Biochemistry, Alex Ekwueme Federal University Ndufu-Alike, Ebonyi State, ${ }^{2}$ Department Science Laboratory \\ Technology, Institute of Management and Technology, Enugu, Enugu State, Nigeria \\ ${ }^{*}$ Corresponding author, E-mail: alokec2002@yahoo.com
}

\begin{abstract}
Accumulating evidences have reinforced the use of medicinal plants in the treatment of various ailments as a result of negative side effects associated with conventional drugs. Plant components such as phenols and flavonoids with antioxidant potential have confirmed protective roles against oxidative stress-induced degenerative diseases like diabetes mellitus (DM). The current study was carried out to investigate the effect of seed pod ethanol extract from Copaifera salikounda(SPEECS) in alloxan-induced diabetic rats. SPEECS was obtained by maceration of seed pod powder in absolute ethanol for $72 \mathrm{~h}$, filtered, concentrated and dried in-vacuo. Gas chromatography-mass spectrometry (GC-MS) technique was used to quantitatively elucidate the chemical constituents of SPEECS. Twenty-four male albino rats were randomly allocated into four groups ( $\mathrm{n}=6$ ): normal control, $\mathrm{DM}$ control, $\mathrm{DM}+200 \mathrm{mg} / \mathrm{kg}$ SPEECS and DM $+400 \mathrm{mg} / \mathrm{kg}$ SPEECS groups. DM was induced in the Wistar albino rats through intraperitoneal injection of $200 \mathrm{mg} / \mathrm{kg}$ body weight of alloxan. After 14 days of treatment, the body weight changes and the fasting blood glucose level were determined in the different groups. Also, serum biochemical parameters such as alanine aminotransferase (ALT), aspartate aminotransferase (AST), alkaline phosphatase (ALP), albumin (ALB), total protein (TP), malondialdehyde (MDA), superoxide dismutase (SOD) and catalase (CAT) were estimated. The GC-MS results confirm nine bioactive compounds with 9-octadecenoic acid (55.75\%) being most abundant. SPEECS (200 and $400 \mathrm{mg} / \mathrm{kg}$ ) administration significantly $(P<0.05)$ caused gain in weight, decreased fasting blood glucose and reversed the elevated liver function enzymes (ALT, AST, ALP) while total TP and ALB were markedly elevated relative to DM control group. Furthermore, SPEECS attenuated the activities of SOD and CAT while the level of MDA was significantly $(P<0.05)$ decreased in dose dependent manner in comparison to the DM control. This study indicated that SPEECS can alleviate hyperglyceamia of DM.
\end{abstract}

Key words: Copaifera salikounda; oxidative stress; medicinal plants; diabetes mellitus; phytochemicals; orthodox

\section{Introduction}

Diabetes mellitus (DM) is an important world health challenge and is associated with elevated level of blood glucose. This condition is orchestrated by total or relative lack of insulin or inability of the cells to respond to insulin produced by the $\beta-$ cells of the islets of Langerhans in the pancreas, manifesting as hyperglycemia and abnormalities in carbohydrate, protein and fat metabolism (1, 2 ). The use of animal models is one of the best methods for the elucidation of the disordered physiological processes of any ailment in order to

Received:23March 2020

Accepted for publication: 24 November 2020 draw a blueprint for the manufacture of drugs for its treatment (3). Alloxan has been widely acknowledged to selectively damage the pancreatic insulin-producing $\beta$-cells, thus employed for DM induction in experimental animals. It produces injurious effect on the $\beta$-cells of the pancreas by the oxidation of sulphydryl group (SH-group), production of free radicals; glucokinase enzyme inhibition and interference in the intracellular calcium balance (4). Thus, it induces oxidative

The mitochondria serve as the primary source of reactive oxygen species (ROS) in cells resulting from imperfectly coupled electron transport. It has been reported that oxidative stress contributes substantially in the development and continuation of DM and its complications, as a result of elevated formation of free radicals and 
compromised antioxidant defenses (6). Oxidative stress in diabetic subjects is mediated by different mechanisms particularly chronic exposure to elevated blood glucose. Previous studies reported that hyperglycemia can elicit the generation of ROS and reactive nitrogen species (RNS) by the mitochondrial respiratory system (7), autoxidation of glucose (8), polyol pathway activation (9), production of advanced glycation end products (AGEs) (10), compromised enzyme antioxidant system (11) and disproportionate glutathione reduction/oxidation status (12). Also, high blood glucose can promote an important oxidative disparity, favoring the production of free radicals and the reduction of antioxidant defenses. Increased concentrations of ROS/RNS can culminate in the impairment of major components of the cellular structure, nucleic acids, proteins, amino acids, and lipids (13). These oxidative alterations in the DM condition would impact several cell functions, metabolism, and gene expression, which will consequently bring about other disease conditions (14).

The use of folklore medicine in the management of DM is of immense importance due to their relative safety and low cost (2). Scientific exploration into the use of these herbal medicines demonstrated that they enhance secretion of insulin, facilitate the intake of glucose by adipose or muscle tissues and prevent the absorption of glucose from the intestine and its production by the hepatocyte (15). A nutritional diet rich in antioxidants is helpful to circumvent oxidative stress-induced diabetes mellitus (16). Some synthetic drugs with the potential to lower blood glucose such as metformin, rosiglitazone, sulphonylureas and thiazolidinediones are available for the management of DM (17). However, prolonged usage of these orthodox anti-diabetic agents poses potential negative side effects. The high cost and negative side effects associated with these drugs limit their usage in developing countries including Nigeria in the management of DM (18). Thus, identification of novel, potent and efficacious natural remedies for treatment of DM has drawn the attention of many researchers (19).

Copaifera salikounda (C. salikounda) (Heckel) is a deciduous medium-sized to large tall tree (up to $50 \mathrm{~m}$ tall) that belongs to the family Caesalpiniaceae (Leguminosae - Fabaceae). The plant has seed pod which contains only one seed. It is a timber tree of commercial importance which is limited because of its restricted distribution and scattered occurrence. It is distributed from Guinea Bissau eastward to Ghana. The wood is used in production of veneer and in furniture making. Aromatic resin obtained from the wood and bark is used locally in making a scented unguent for cosmetic use. The pounded bark is applied on the body as a perfume in Liberia. The pulped leaves of $C$. salikounda have been reported to be employed in treatment of sores or as hot poultice while the dried leaves and bark blended with baked and powdered clay are employed in ulcer management. Furthermore, an infusion of the fruit valve is employed as blood cleanser whereas a cold extract of the seed is used in vertigo treatment (20). The seed pod of $C$. salikounda is used as food ingredient and in treatment of rheumatoid arthritis (21). Aloke et al. (21) had reported the presence of the following phytochemicals in the seed pod of $C$. salikounda in order of their abundance as follows: total phenolics > alkaloids > terpenoids $>$ carbohydrates $>$ flavonoids $>$ reducing sugar $>$ tannins $>$ glycosides $>$ steroids. There is paucity of scientific information on the use of the seed pod ethanol extract from Copaifera salikounda (SPEECS) for the management of DM. The current study was done based on personal communications and interviews from different traditional medicine practitioners that affirm the ethno-medicinal use of SPEECS in treating hyperglycemia. This work therefore, is the first documented proof of the antidiabetic potential of SPEECS.

This study investigated the ability of SPEECS produced in a process similar to the practice of folklore medicine practitioners, to alleviate hyperglycemia and oxidative stress in diabetic rats. The findings are anticipated to support the traditional usage and claim of efficacy and scientifically rationalize the traditional therapy in the management of diabetic conditions.

\section{Materials and methods}

\section{Materials}

Dried samples of seed pods of $C$. salikounda were collected in a farmland at Umuigboke Ugwulangwu in Ohaozara Local Government of Ebonyi State, Nigeria. The plant was identified and authenticated by a taxonomist, Mr. Alfred Ozioko at the International Centre for Ethnomedicine and Drug Development Nsukka, Enugu State with voucher specimen no:InterCEDD/16281. 
All chemicals used were of analytical grade and were purchased from Sigma Aldrich, Saint Louis, U.S.A.

\section{Seed pod extract preparation}

The seed pods of $C$. salikounda were further dried in the shade after washing with water. They were then ground using mortar and pestle. The ground seed pods obtained were passed through the sieve to obtain its powdered form. The ethanol extract was prepared by maceration of $103.3 \mathrm{~g}$ of seed pod powder in $500 \mathrm{ml}$ of absolute ethanol for 72 hours. Then, the extract was filtered, concentrated, and dried in-vacuo. The percentage yield of the extract was $38.9 \%$. See Figure 1 for the plate showing the seed pod C. salikounda.

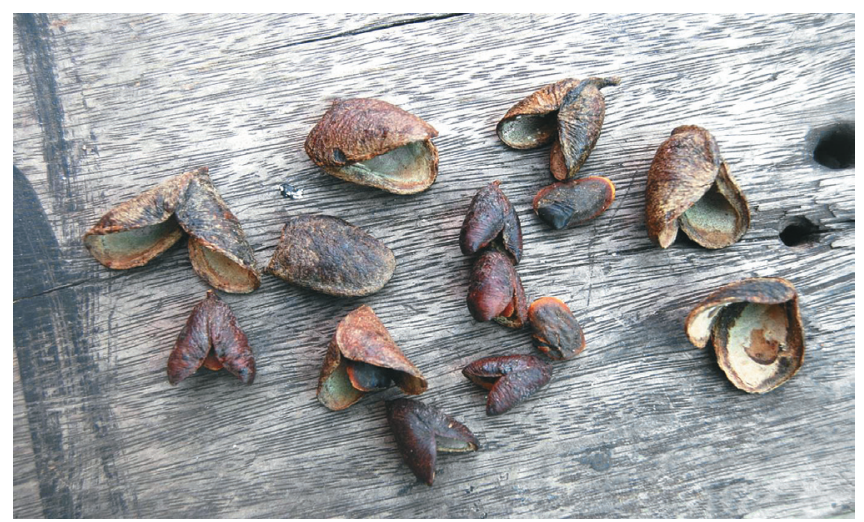

Figure 1: Plate showing the seed pod of $C$. salikounda with some seeds

Seven weeks old male Wistar albino rats (110 $150 \mathrm{~g}$ ) obtained from Faculty of Veterinary Medicine, University of Nigeria, Nsukka, Enugu State, Nigeria were used for this study. The rats were housed in the Animal House, Alex Ekwueme Federal University Ndufu-Alike, Ikwo, Ebonyi State, Nigeria. They were kept in well-ventilated cages at room temperature. The rats were fed a standard rat pellet (Vital Feed Nig., Ltd) and water. The rats were acclimatized for a period of seven days prior to the induction of experimental diabetes mellitus. The present study was performed according to international, national and institutional rules considering animal experiments, clinical studies and biodiversity rights. Approval for this study was given by the Academic Board of Department of Medical Biochemistry and Institutional Animal Ethical Committee of Alex Ekwueme Federal University Ndufu-Alike Ikwo, Nigeria with ethical code no: FBMS/EC/AE/2352 prior to the commencement of the experiments in line with the National Institute of Health's ethical guidelines for the care and usage of laboratory animals.

\section{Gas Chromatography - Mass spectrometry (GC-MS) analysis}

Using gas chromatographic mass spectrometry, the phytochemical compounds of seed pod ethanol extract from $C$. salikounda were determined using GC-MSQP2010 Shimadzu system linked with a GC column (2010) coated with polymethyl silicon $(0.25 \mathrm{~nm} \times 50 \mathrm{~m})$. Using programmed temperature from 80 to $200 \mathrm{oC}$ and held for $80 \mathrm{oC}$ for $1 \mathrm{~min}$ at rate of $5 \mathrm{oC} / \mathrm{min}$ and $200 \mathrm{oC}$ for $20 \mathrm{mins}$, the detector and injector were set to a temperature of $300 \mathrm{oC}$ and $220 \mathrm{oC}$ respectively while the flow rate of the nitrogen carrier gas was $1 \mathrm{ml} / \mathrm{min}$ and the split ratio 1:75. Gas chromatography mass spectrum was performed using GC-MS QP 2010 in conjunction with Shimadzu Japan with the injector temperature of $220 \mathrm{oC}$ and pressure of the carrier gas at $116.9 \mathrm{kpa}$ while the column length and diameter were $30 \mathrm{~m}$ and $0.25 \mathrm{~mm}$ respectively and the flow rate was $50 \mathrm{ml} / \mathrm{min}$. The elutes were accordingly run into a mass spectrometer with a dictator voltage set at $1.5 \mathrm{kv}$ and sampling rate of $0.2 \mathrm{sec}$. The mass spectrum was also furnished with a computer fed mass spectra data bank. Hermlez 233 M-Zcentrifuge (Germany) was used. Components identification was verified based on the relative retention time and mass spectra with computer Wiley Libraries and thus confirmed by mass spectra comparison of the peaks and those from literature (22).

\section{Acute toxicity test}

The acute toxicity test was conducted to determine the median lethal dose $\left(\mathrm{LD}_{50}\right)$ of SPEECS and to choose the safe dose for the treatment. Acute toxicity study of SPEECS was carried out based on Lorke method with slight modifications (23). Thirty-six (36) rats were used for the acute toxicity test. Prior to the acute toxicity study, the rats were weighed and fasted overnight and were assigned into two experimental groups, A and B. Group A with four rats served as the normal control group and was administered normal saline. The Group B received SPEECS. Group B was further sub-divided into eight groups with 
each group having four rats. The sub-groups were orally given SPEECS at 200, 400, 800, 1200, $1800,2000,3000$ and $5000 \mathrm{mg} / \mathrm{kg}$ body weight respectively and the test animals were observed for 24 hours. Furthermore, the rats in the different groups were monitored for the first 2 hours for behavioral changes and morbidity and up to 72 hours for mortality.

\section{Experimental design}

\section{Induction of $D M$}

DM was induced in the Wistar albino rats after depriving them food overnight by intraperitoneal (IP) injection of $200 \mathrm{mg} / \mathrm{kg}$ body weight of freshly prepared alloxan dissolved in normal saline (24). Thereafter, the rats were fasted overnight after three days of injection of alloxan and their blood glucose determined using glucometer (Accu-Chek, Boerhinger Mannheim, Germany). Rats with fasting blood glucose $\geq 200 \mathrm{mg} / \mathrm{dl}$ on the third day after injection of alloxan were selected for the study.

\section{Experimental groups.}

A total of 24 male Wistar albino rats were used. The rats were randomly allocated into 4 groups of 6 rats each as follows:

- Normal Control $=$ Normal control (received only normal saline $1.0 \mathrm{~mL} / \mathrm{kg}$ body weight).

- $\mathrm{DM}=$ Diabetic rats not treated, received only normal saline $1.0 \mathrm{~mL} / \mathrm{kg}$ body weight.

- DM + SPEECS $(200 \mathrm{mg} / \mathrm{kg})=$ Diabetic rats treated with $200 \mathrm{mg} / \mathrm{kg}$ body weight SPEECS per os daily for 14 consecutive days

- DM + SPEECS $(400 \mathrm{mg} / \mathrm{kg})=$ Diabetic rats treated with $400 \mathrm{mg} / \mathrm{kg}$ body weight SPEECS per os daily for 14 consecutive days

\section{Body weight determination}

The rats were weighed at three different times using a digital weighing balance. These measurements were done before induction of experimental DM, 72 hours after induction of DM and after the 14 days of SPEECS administration.

\section{Collection of blood sample}

Fourteen days after administration of SPEECS, the rats were fasted overnight and five rats from each group were humanely euthanized by cervical dislocation and their blood samples were collected through cardiac puncture into labeled plain sample tubes. The samples were centrifuged using a standard centrifuge at $4000 \mathrm{x}$ g for 10 minutes and the sera were obtained for biochemical analysis.

\section{Determination of fasting blood glucose}

The fasting blood glucose levels of the rats were determined using "Accu-Chek Active Glucometer" and blood glucose test strips (Roche Diagnostics, Mannheim, Germany) before induction of experimental DM and 72 hours after induction of DM. The fasting blood glucose levels were also measured after the 14-day administration of SPEECS before the rats were sacrificed.

\section{Determination of biochemical parameters}

The serum activities of ALT and AST were determined spectrophotometrically (25) while ALP activity was determined using previously established method (26). The level of total protein was determined using colorimetric Biuret method (27) while serum albumin was determined using bromcresol green method (28).

\section{Assessment of lipid peroxidation and anti- oxidant status.}

Malondialdehyde (MDA) in serum was determined spectrophotometrically by measuring thiobarbituric acid reactive substance (TBARS) (29). Serum activities of superoxide dismutase (SOD) was assessed by the method outlined by Fridovich and Mc-Cord (30) and catalase (CAT) was determined by colorimetric method (31)

\section{Statistical analysis}

All the data were expressed as mean \pm standard deviation. The means were compared using oneway analysis of variance (ANOVA) and significant variation were determined by Duncan multiple range test using SPSS software version 20. Value of $p<$ 0.05 was considered to be statistically significant. 


\section{Results}

\section{GC-MS analysis of SPEECS}

The results of GC-MS analysis of SPEECS gave nine bioactive constituents: n-hexadecanoic acid (8.97\%), 7-octadecanoic acid methy ester (4.73\%), 9-octadecenoic acid (55.75\%), Octadecanoic acid (4.43\%), Phenol, 2-methyl (8.72\%), (E) 8- methyl7-dodecen-1-ol acetate (3.62 \%), Phthanic acid (1.81\%), Cyclopropaneundecanal, 2-Nonyl (4.82\%) and 1,4-benzenediol, 2-methyl (7.15\%) as shown in Table 1.

Table 1: Results from GC-MS analysis of SPEECS

\begin{tabular}{|c|c|c|c|c|c|}
\hline S. NO & Retention Time & $\begin{array}{l}\text { Name of com- } \\
\text { pound }\end{array}$ & $\begin{array}{l}\text { Molecular for- } \\
\text { mula }\end{array}$ & $\begin{array}{l}\text { Molecular weight } \\
\text { (g/mol) }\end{array}$ & Area \% \\
\hline 1 & 17.320 & $\begin{array}{l}\text { n-hexadecanoic } \\
\text { acid }\end{array}$ & $\mathrm{C}_{16} \mathrm{H}_{32} \mathrm{O}_{2}$ & 257.422 & 8.97 \\
\hline 2 & 38.290 & $\begin{array}{l}7 \text {-octadecanoic } \\
\text { acid methy ester }\end{array}$ & $\mathrm{C}_{19} \mathrm{H}_{36} \mathrm{O}_{2}$ & 296.495 & 4.73 \\
\hline 3 & 38.534 & $\begin{array}{l}\text { 9-octadecenoic } \\
\text { acid }\end{array}$ & $\mathrm{C}_{18} \mathrm{H}_{34} \mathrm{O}_{2}$ & 282.468 & 55.75 \\
\hline 4 & 38.659 & $\begin{array}{l}\text { Octadecanoic } \\
\text { acid }\end{array}$ & $\mathrm{CH}_{3}\left(\mathrm{CH}_{2}\right)_{16} \mathrm{COOH}$ & 284.48 & 4.43 \\
\hline 5 & 40.254 & Phenol, 2-methyl & $\mathrm{C} 7 \mathrm{H} 8 \mathrm{O}$ & 108.14 & 8.72 \\
\hline 6 & 40.461 & $\begin{array}{l}\text { (E) 8- methyl-7- } \\
\text { dodecen-1-ol } \\
\text { acetate }\end{array}$ & $\mathrm{C}_{15} \mathrm{H}_{28} \mathrm{O}_{2}$ & 240.382 & 3.62 \\
\hline 7 & 40.723 & Phthanic acid & $\mathrm{C}_{8} \mathrm{H}_{6} \mathrm{O}_{4}$ & 166.14 & 1.81 \\
\hline 8 & 41.812 & $\begin{array}{l}\text { Cyclopropaneun- } \\
\text { decanal, 2-Nonyl }\end{array}$ & $\mathrm{C}_{23} \mathrm{H}_{44} \mathrm{O}$ & 336.595 & 4.82 \\
\hline 9 & 42.675 & $\begin{array}{l}\text { 1,4-benzenediol, } \\
\text { 2-methyl }\end{array}$ & $\mathrm{C}_{7} \mathrm{H}_{8} \mathrm{O}_{2}$ & 124.13 & 7.15 \\
\hline
\end{tabular}

\section{Acute toxicity study}

In acute toxicity testing, no abnormal behavior and mortality were recorded. This indicated that the $\mathrm{LD}_{50}$ was greater than $5000 \mathrm{mg} / \mathrm{kg}$. This formed the basis for the selection of the doses of the extracts administered.

\section{Effect of SPEECS on body weight of al- loxan-induced diabetic rats}

The results of alteration in body weight of the experimental rat groups are presented in Table 2 . The average weight of the normal control group was found to be relatively stable but that of DM control group showed significant $(p<0.05)$ reduction in body weight during the 14 days. The results showed that injection of alloxan caused sharp reduction in body weight of diabetic rats which was reversed by the administration of SPEECS at 200 and $400 \mathrm{mg} /$ $\mathrm{kg}$ after 14 days of treatment. The weight gain in rats after 14 days treatment was higher in group fed with $400 \mathrm{mg} / \mathrm{kg}$ of SPEECS compared to those fed with $200 \mathrm{mg} / \mathrm{kg}$ of SPEECS as shown in Table 2.
Effect of SPEECS on liver function markers of alloxan-induced diabetic rats

The serum concentrations of ALB and TP were low and the activities of ALT, AST and ALP were significantly higher in the DM rats group in comparison with the normal control group. TP level was significantly $(p<0.05)$ elevated in DM group treated with $200 \mathrm{mg} / \mathrm{kg}$ while there was non-signification elevation of ALB concentration when compared with DM control group. The serum activities of ALT, AST and ALP were significantly $(p<0.05)$ lower while the levels of ALB and TP were significantly $(p<0.05)$ higher in DM group treated with $400 \mathrm{mg} / \mathrm{kg}$ relative to DM model rats (Table 3). However, there was significant increase $(p<0.05)$ in the levels of ALB, TP and significant reduction in the actions of AST and ALP in DM + SPEECS $(400 \mathrm{mg} / \mathrm{kg}$ ) when compared with DM + SPEECS $(200 \mathrm{mg} / \mathrm{kg}$ ) while the activity of ALT reduced but not statistically significant (Table 3). 
Table 2: Effect of SPEECS on body weight of alloxan-induced diabetic rats

\begin{tabular}{llll}
\hline Group & \multicolumn{2}{c}{ Body weight $(\mathrm{g})$} \\
\hline & Day 1 & Day 7 & Day 14 \\
Control & $137.9 \pm 1.87$ & $147.7 \pm 2.30$ & $148.1 \pm 2.42$ \\
DM & $125.2 \pm 3.22^{*}$ & $115.4 \pm 2.71^{*}$ & $116.1 \pm 2.69^{*}$ \\
DM + SPEECS (200 mg/kg) & $125.7 \pm 4.82^{\#}$ & $128.5 \pm 2.78^{\#}$ & $128.5 \pm 2.78^{\#}$ \\
DM + SPEECS (400 mg/kg) & $120.6 \pm 2.10^{\star *}$ & $133.9 \pm 1.43^{\#}$ & $134.1 \pm 1.45^{\#}$ \\
\hline
\end{tabular}

Results are expressed as mean \pm SEM $(n=5)$. DM: Diabetes mellitus; $\mathrm{P}<0.05$ was considered significant. ${ }^{*} \mathrm{p}<0.05$ : the difference is significant compared to control group in the same column; \#p < 0.05: the difference is significant compared to DM group in the same column; ${ }^{\mathrm{p}}<$ < 0.05 : the difference is significant compared to DM + SPEECS $(200 \mathrm{mg} / \mathrm{kg})$ group in the same column. DM + SPEECS $(200 \mathrm{mg} / \mathrm{kg})$ : Diabetic rats treated with $200 \mathrm{mg} / \mathrm{kg}$ b.w seed pod ethanol extract from C. salikounda; DM + SPEECS (400 mg/kg): Diabetic rats treated with $400 \mathrm{mg} / \mathrm{kg}$ b.w seed pod ethanol extract from C. salikounda; SPEECS: Seed pod ethamol extract from C. salikounda

\section{Effect of SPEECS on liver function markers of alloxan-induced diabetic rats}

The serum concentrations of ALB and TP were low and the activities of ALT, AST and ALP were significantly higher in the DM rats group in comparison with the normal control group. TP level was significantly $(p<0.05)$ elevated in DM group treated with $200 \mathrm{mg} / \mathrm{kg}$ while there was non-signification elevation of ALB concentration when compared with DM control group. The serum activities of ALT, AST and ALP were significantly $(p<0.05)$ lower while the levels of ALB and TP were significantly $(p<0.05)$ higher in DM group treated with $400 \mathrm{mg} / \mathrm{kg}$ relative to DM model rats (Table 3). However, there was significant increase $(p<0.05)$ in the levels of ALB, TP and significant reduction in the actions of AST and ALP in DM + SPEECS $(400 \mathrm{mg} / \mathrm{kg})$ when compared with DM + SPEECS $(200 \mathrm{mg} / \mathrm{kg})$ while the activity of ALT reduced but not statistically significant (Table 3 ).

Table 3: Effect of SPEECS on biochemical parameters of alloxan-induced diabetic rats

\begin{tabular}{llllll}
\hline Groups & ALT (U/L) & AST (U/L) & ALP (U/L) & ALB (g/L) & TP (g/L) \\
\hline Normal Control & $37.5 \pm 0.69$ & $59.6 \pm 0.86$ & $31.5 \pm 0.86$ & $3.47 \pm 0.17$ & $5.3 \pm 0.11$ \\
DM & $42.8 \pm 1.72^{*}$ & $75.4 \pm 0.77^{*}$ & $57.7 \pm 1.11^{*}$ & $3.19 \pm 0.21$ & $5.1 \pm 0.08$ \\
DM + SPEECS (200 mg/kg) & $33.4 \pm 1.22^{\#}$ & $61.6 \pm 0.82^{\#}$ & $45.9 \pm 0.60^{\#}$ & $3.22 \pm 0.11$ & $5.5 \pm 0.09^{\#}$ \\
DM + SPEECS (400 mg/kg) & $30.5 \pm 0.56^{\#}$ & $51.6 \pm 1.11^{\# \&}$ & $38.8 \pm 0.84^{\# \&}$ & $3.91 \pm 0.10^{\# \approx}$ & $5.9 \pm 0.06^{\# \&}$ \\
\hline
\end{tabular}

Results are expressed as mean \pm SEM $(n=5)$. DM: Diabetes mellitus; $\mathrm{P}<0.05$ was considered significant. ${ }^{*} \mathrm{p}<0.05$ : the difference is significant compared to control group in the same column; \#p < 0.05: the difference is significant compared to DM group in the same column; ${ }^{\circledR}$ p $<0.05$ : the difference is significant compared to DM + SPEECS $(200 \mathrm{mg} / \mathrm{kg})$ group in the same column. DM + SPEECS (200 mg/ $\mathrm{kg})$ : Diabetic rats treated with $200 \mathrm{mg} / \mathrm{kg}$ b.w seed pod ethanol extract from C. salikounda; DM + SPEECS (400 mg/kg): Diabetic rats treated with $400 \mathrm{mg} / \mathrm{kg}$ b.w seed pod ethanol extract from C. salikounda; SPEECS: Seed pod ethamol extract from C. salikounda. ALT: alanine aminotransferase; AST: aspartate aminotransferase; ALP: alkaline phosphatase; TP: total protein; ALB: albumin.

\section{Effect of SPEECS on fasting blood glucose level of alloxan-induced diabetic rats}

The glucose lowering effect of the ethanol extract of seed pod $C$. salikounda is shown in Figure 2. The fasting blood glucose of alloxaninduced diabetic rats three days after injection of alloxan were significantly increased $(p<0.05)$ in comparison with the normal control rats. The blood glucose level of the groups treated with 200 and $400 \mathrm{mg} / \mathrm{kg}$ of the ethanol extracts seed pod of C. salikounda decreased significantly $(p<0.05)$ after 14 days of treatment in comparison to the DM control group. However, there was significant blood glucose level reduction in the group treated with $400 \mathrm{mg} / \mathrm{kg}$ of the extract in comparison to the group treated with $200 \mathrm{mg} / \mathrm{kg}$. This showed that the effect of the extract was dose dependent. 


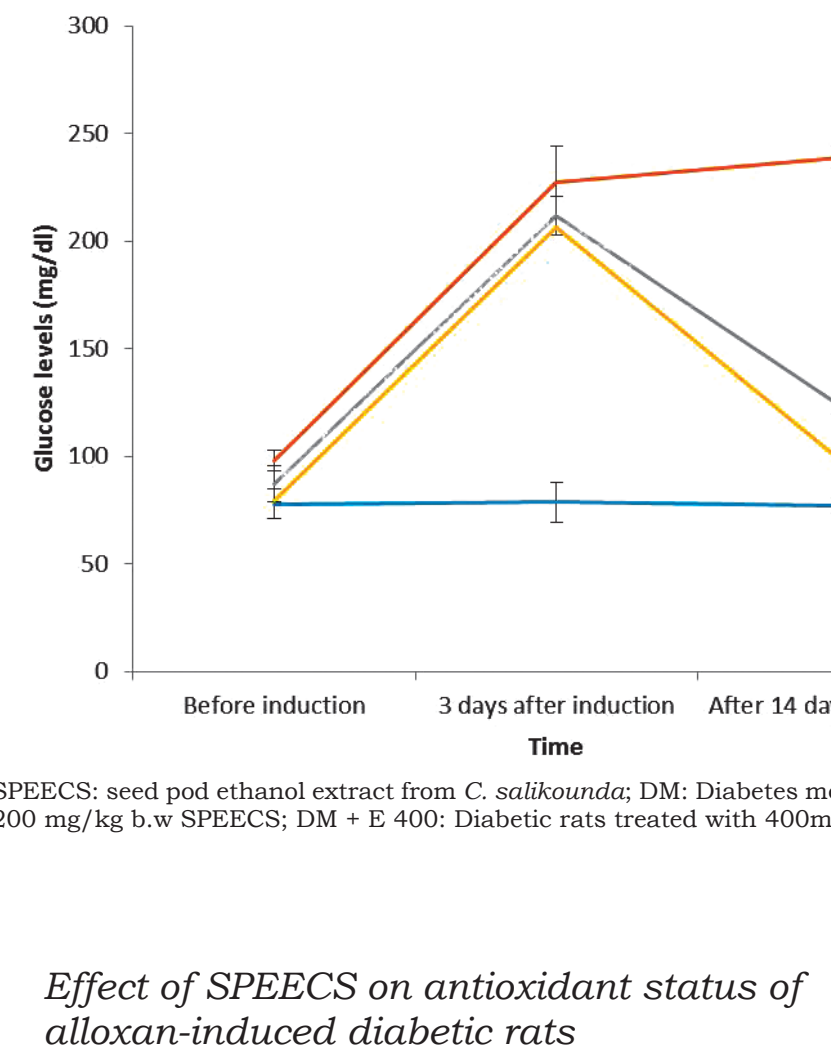

The serum activities of SOD and CAT were markedly $(p<0.05)$ higher in DM control group compared to the normal control group (Figure $3 \mathrm{~A}-\mathrm{B}$ ). The activities of SOD and CAT were significantly $(p<0.05)$ lower in diabetic groups treated with 200 and $400 \mathrm{mg} / \mathrm{kg}$ SPEECS. Besides, the activities of SOD and CAT were significantly lower in diabetic rats treated with $400 \mathrm{mg} / \mathrm{kg}$ when compared with those treated with $200 \mathrm{mg} / \mathrm{kg}$. This is an indication that $400 \mathrm{mg} / \mathrm{kg}$ of the extract is more potent and efficacious (Figure $3 \mathrm{~A}-\mathrm{B}$ )

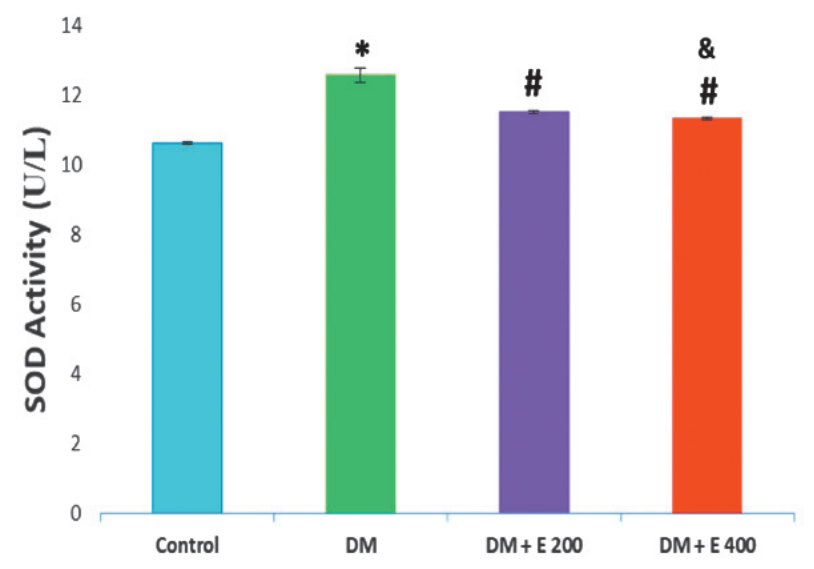

A

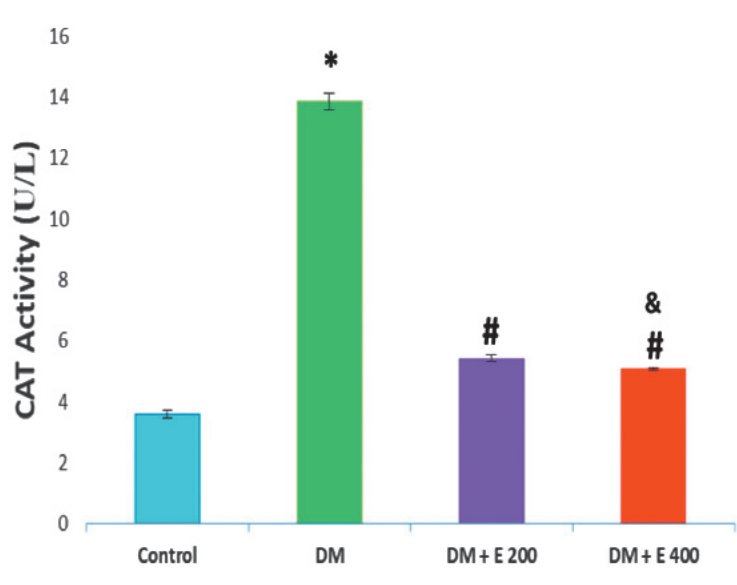

$\mathbf{B}$

Figure 3: (A-B) Effect of SPEECS on antioxidant status in alloxan-induced diabetic rats $(n=5)$

SPEECS: seed pod ethanol extract from Copaifera salikounda; $p<0.05$ was considered significant. * $p<0.05$ : the difference is significant compared to control group; \#p<0.05: the difference is significant compared to DM group; ${ }^{8} p<0.05$ : the difference is significant compared to DM + Extract (200 $\mathrm{mg} / \mathrm{kg}$ ) group; DM: Diabetes mellitus group without any treatment; DM + E 200: Diabetic rats treated with 200 mg/kg b.w SPEECS; DM + E 400: Diabetic rats treated with $400 \mathrm{mg} / \mathrm{kg}$ b.w SPEECS; SOD: Superoxide dismutase; CAT: Catalase. 


\section{Effect of SPEECS on serum MDA level in alloxan-induced diabetic rats}

The serum concentration of MDA at the end of the experiment in the DM model rats was significantly $(p<0.05)$ higher in comparison with the normal control group. However, this effect was reversed following 14 days treatment with 200 and $400 \mathrm{mg} / \mathrm{kg}$ of the extract in the treated groups. Additionally, the MDA level was significantly lower in the group treated with $400 \mathrm{mg} / \mathrm{kg}$ of the extract in comparison to diabetic rats that received 200 $\mathrm{mg} / \mathrm{kg}$ of the extract (Figure 4) showing that the extract is more effective at $400 \mathrm{mg} / \mathrm{kg}$ dose.

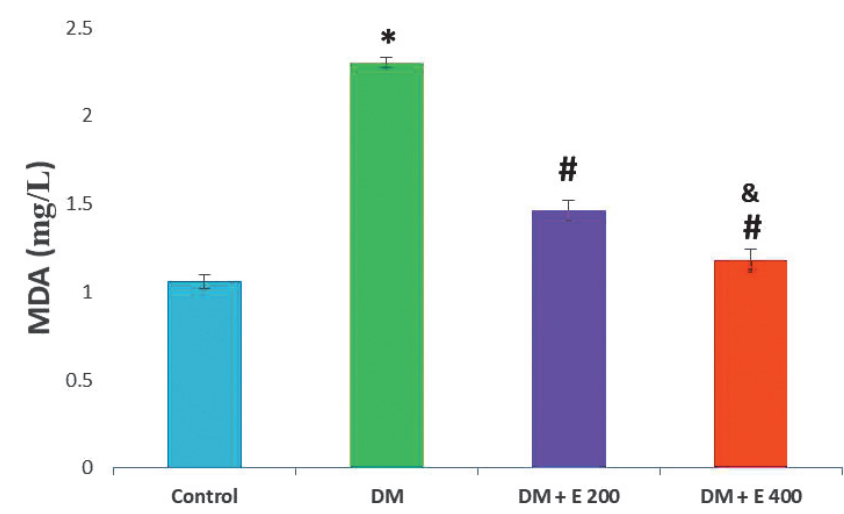

Figure 4: Effect of SPEECS on serum MDA level in alloxan-induced diabetic rats $(n=5)$.

SPEECS: seed pod ethanol extract from Copaifera salikounda; DM: Diabetes mellitus; $p<0.05$ was considered significant. $* p<0.05$ : the difference is significant compared to control group; $\# p<0.05$ : the difference is significant compared to DM group; ${ }^{\circ} p<0.05$ : the difference is significant compared to DM + Extract $(200 \mathrm{mg} / \mathrm{kg})$ group; DM: Diabetes mellitus group without any treatment; DM + E 200: Diabetic rats treated with $200 \mathrm{mg} / \mathrm{kg}$ b.w SPEECS; DM + E 400: Diabetic rats treated with $400 \mathrm{mg} / \mathrm{kg}$ b.w SPEECS; MDA: Malondialdehyde

\section{Discussion}

Robust evidence has shown that plants are exemplary source of drugs. Currently, several available drugs have been produced from medicinal plants either directly or indirectly (32). Some studies have shown that a wide variety of plant extracts profoundly lowered blood glucose level in alloxan-induced diabetic animals $(32,33$, $34,35)$. The results of this study showed that SPEECS has antihyperglycemic effect on alloxaninduced DM in Wistar albino rats

Report on the quantification of the chemical components in the seed pod of $C$. salikounda indicated that it is predominantly rich in total phenolics, alkaloids, terpenoids, flavonoids, tannins, steroids, glycosides, reducing sugar and carbohydrates (21). In this study, the GC-MS analysis of SPEECS revealed the presence of known a-glucosidase inhibitors such as 9-octadecenoic acid and octadecanoic acid in the ethanol extracts. The inhibition of a-glucosidase has been reported to be a possible mechanism in treating DM by enzyme inhibition (36) and this affirms possible anti-hyperglycemic effects of SPEECS in this study. Other reports have shown the anti-diabetic property as well as release of insulin stimulation potential of hexadeconoic acid and octadecenoic $(37,38)$. Thus, the GC-MS identified compounds in this study: 9-octadecenoic acid, octadecanoic acid and hexadecanoic acid may be the potential anti-diabetic agents in the extract which may have exerted their effect via stimulation of insulin release and a-glucosidase inhibition. The findings in this study revealed that SPEECS contains bioactive compounds which mitigated hyperglyceamia and oxidative stress in alloxaninduced diabetic rats and restored the alteration in their body weights. The administration of alloxan produced a significant oxidative impact as evidenced by elevation of lipid peroxidation (MDA) and disturbances in antioxidant enzymes status.

The ability of alloxan to induce weight loss in untreated rats (DM control group) mimics what is commonly seen in clinical diabetes mellitus (39). This loss in weight could be as result of destruction of the pancreatic cells by alloxan leading to insulin deficiency which causes increased ketone bodies production. Consequently, elevated ketone bodies with increased lipolysis result in loss of body weight (40). The gain in body weight observed in diabetic rats treated with SPEECS could be attributed to better modulation of hyperglycemia in the diabetic rats and reduction in fasting blood glucose which could improve body weight in alloxan-induced diabetic rats (41). Additionally, the ability of SPEECS to improve body weight may be due to its ability to lower the elevated blood glucose via increased glucose metabolism, and this may be attributed to the protective effect of the extract in preventing muscle wasting (42).

The results of this study have shown that SPEECS at a dosage of 200 and $400 \mathrm{mg} / \mathrm{kg}$ body weight significantly $(P<0.0001)$ decreased the elevated blood glucose levels compared to normal rats. The glucose lowering effect of SPEECS (Figure 2) may be attributed to the enhanced secretion of insulin from the beta cells of pancreas or may be due to increased tissue uptake of glucose by enhancement 
of insulin sensitivity (43). Additionally, other mechanisms that could have accounted for reduction in blood glucose level include: 1) the ability of the extract to function as an astringent enhancing the precipitation of intestinal mucus membrane protein and formation of a bilayer that shield the intestine and prevent glucose uptake, 2) the ability of the extract to speed up glucose liberation from circulation by promoting its filtration and renal excretion, and 3) promotion of glucose liberation via enhanced metabolism and inclusion into fats depots, an action requiring the pancreas to make insulin (44). Flavonoids have been reported as strong bioactive antioxidant and anti-diabetic agents that can regulate insulin secretion. Flavonoid hinders the action of hepatic glucose-6-phosphatase thereby preventing gluconeogenesis and breakdown of glycogen and consequently brings down elevated blood glucose (45). The presence of flavonoids and saponins in SPEECS (21) could have led to the revival of the non-functional beta cells by the flavonoid and prevention of the glucose transport by inhibiting intestinal sodium glucose co-transporter-1(SGLUT-1) by the saponins $(46,47)$. Also, saponins have been shown to exhibit blood glucose lowering potential (48). The blood glucose lowering potential of SPEECS may be due to the synergy of its phytochemical constituents.

Additionally, hyperglycemia increases the generation of free radicals by glucose autooxidation and the increment of free radicals may lead to liver damage (49). The liver is necrotized in diabetic rats. This leads to increased activities of ALT, AST and ALP enzymes as they leak from the liver membrane into the blood stream and as such serves as indicators of the hepatotoxicity of alloxan (50). The significant $(P<0.05)$ elevation of serum enzymes such as ALT, AST and ALP observed in diabetic mellitus control rats as compared to normal control rats might be due to the leakage of these enzymes from the liver membrane into the blood stream (51). However, the oral administration of SPEECS significantly $(P<0.0001)$ decreased the elevated serum enzymes and implied heptato-protective effects (Table 3 ).

The functional capacity of the hepatocyte is measured by total protein content as the liver is provided with mechanism for the production of serum protein excluding $\gamma$-globulins. Hence, injury to the liver is marked by decrease in the level of protein in the blood and reduced Alb which can affect the body functions of animals (52). Disruption of protein synthesis is a consequence of decline in liver function (53). The observed decrease in Alb level in diabetes mellitus control group in this study could be a result of a decline in the number of cells responsible for Alb synthesis in the liver through necrosis by diabetogenic agent, alloxan. However, treatment with SPEECS at doses 200 and $400 \mathrm{mg} / \mathrm{kg}$ significantly $(P<0.05)$ increased serum TP and Alb in a dose dependent manner suggesting increased protein synthesis probably due to the regeneration of the damaged liver cells by the SPEECS.

Physiochemical processes in the body produce ROS which can participate in various reactions that when not controlled will lead to some clinical signs (54). Oxidative stress caused by excessive production of superoxide and compromised antioxidant enzymes has been associated with development of clinical conditions attributed to DM. DM is one of the disease conditions that is linked with immoderate generation of ROS like hydrogen peroxide $\left(\mathrm{H}_{2} \mathrm{O}_{2}\right)$, hydroxyl radical (HO-) and superoxide anions $\left(\mathrm{O}^{2-}\right)$. Consequently, cells must be safeguarded from this oxidative damage by antioxidant enzymes (52). This study found a significantly elevated activity of SOD and CAT in diabetic rats when compared with the normal control. Excessive generation of ROS particularly in DM cannot be completely mopped up by antioxidant enzymes. Thus, when oxidative stress occurs as a result of disease condition, the body system enhances the induction or up regulation of these enzymes (55). The alteration in the activity of these enzymes might be due to altered metabolism occasioned by induction of DM with alloxan. However, treatment with SPEECS attenuated the activity of SOD and CAT at the tested concentrations.

MDAis a breakdown product oflipid peroxidation of polyunsaturated fatty acid in the membrane of cells. In this study, the presence of elevated level of MDA in diabetic rats when compared with control is suggestive of induced peroxidation of lipid and oxidative stress which has been revealed to be implicated in DM (56). Treatment with the SPEECS significantly reduced the MDA level relative to the DM control group (Figure 4). The total anti-diabetic effect of SPEECS may be due to the combined action of their phytcomponents irrespective of their amount. Consequently, the significant antidiabetic action of SPEECS in this 
work may be ascribed to the presence of alkaloids, flavonoids, phenols, steroids or terpenoids and other constituents that could act independently or in synergy to scavenge free radicals, hence safeguarding the islet of Langerhans from injury and death.

This study, however, has limitations due to financial constraints as the experiment leading to the exact mechanism of the extract could not be done. We did not include a reference drug in the study to compare its effect on the diabetic rats with that of the extract. Besides, a longer period of three weeks would have been better to evaluate the efficacy of the extract.

In conclusion the results of this study indicated that SPEECS has anti-diabetic and anti-oxidative potentials. These findings corroborate its usage in the management of diabetes mellitus in traditional medicine and advocate for more research to harness fully the potentials of $C$. salikounda for treatment of DM.

\section{Acknowledgements}

The authors declare there is no conflict of interest.

We declare that this work was fully funded by the authors and no grant was received by the authors.

The authors are grateful to Prof. Ejike C.E.C.C. for his invaluable comments and contributions to this work.

\section{References}

1. Ionut V, Amorin RP. Epidemiology of diabetes mellitus: a current review. Rom J Diabetes Nutr Metab Dis 2012; 19(4): 433-40. doi: 10.2478/ v10255-012-0050-0

2. Osadebe PO, Uzor PF, Omeje E O, Agbo MO, Obonga WO. Hypoglycemic activity of the extract and fractions of Anthocleista vogelii (Planch) stem bark. Trop J Pharm Res 2014; 13: 1437-43. doi: 10.4314/tjpr.v13i9.9

3. Chatzigeorgiou A, Halapas A, Kalafatakis K, Kamper E. The use of animal models in the study of diabetes mellitus. In Vivo 2009; 23: 245-58.

4. Dhanesha N, Joharapurkar A, Shah G, et al. Exendin-4 ameliorates diabetic symptoms through activation of glucokinase. J Diabetes 2012; 4(4): 369-77. doi: 10.1111/j.1753-0407.2012.00193.x
5. Bhat AH, Dar KB, Zargar MA, Masood A, Ganie SA. Modulation of oxidative stress and hyperglycemia by Rheum spiciformis in alloxan induced diabetic rats and characterization of isolated compound. Drug Res (Stuttg). 2018; 69(4): 218-26. doi: 10.1055/a-0665-4291

6. Ceriello A. New insights on oxidative stress and diabetic complications may lead to a "causal" antioxidant therapy. Diabetes Care 2003; 26(5): 1589-96. doi:10.2337/diacare.26.5.1589

7. Nishikawa T, Araki E. Impact of mitochondrial ROS production in the pathogenesis of diabetes mellitus and its complications. Antioxid Redox Sign 2007; 9(3): 343-53. doi:10.1089/ ars.2007.9.ft-19

8. Yorek MA. The role of oxidative stress in diabetic vascular and neural disease. Free Radic Res 2003; 37(5): 471-80.

9. Cameron NE, Cotter MA, Hohman TC. Interactions between essential fatty acid, prostanoid, polyol pathway and nitric oxide mechanisms in the neurovascular deficit of diabetic rats. Diabetologia 1996; 39(2): 172-82. doi: 10.1007/BF00403960

10. Monnier VM. Intervention against the Maillard reaction in vivo. Arch Biochem Biophys 2003; 419(1): 1-15.

11. Maritim AC, Sanders RA, Watkins JB. Diabetes, oxidative stress, and antioxidants: a review. J Biochem Mol Toxicol 2003; 17(1): 24-38. doi:10.1002/jbt. 10058

12. Kaneto H, Fujii J, Suzuki K, et el. DNA cleavage induced by glycation of $\mathrm{Cu}, \mathrm{Zn}$-superoxide dismutase. Biochem J 1994; 304(1): 219-25. doi: 10.1042/bj3040219

13. Valko M, Leibfritz D, Moncol J, et al. Free radicals and antioxidants in normal physiological functions and human disease. Int $\mathrm{J}$ Biochem Cell Biol 2007; 39(1): 44-84. doi:10.1016/j.biocel.2006.07.001

14. Young IS, Woodside JV. Antioxidants in health and disease. J Clin Pathol 2001; 54(3): 176-86. doi:10.1136/jcp.54.3.176

15. Hui H, Tang G, Go VLW. Hypoglycemic herbs and their action mechanisms. Chin Med 2009; 4: e11. doi: 10.1186/1749-8546-4-11

16. Berraaouan A, Abid S, Bnouham M, Berraaouan A. Antidiabetic oils. Curr Diabetes Rev 2013; 9: 499-505.

17. Nathan DM, Buse JB, Davidson MB, et al. Medical management of hyperglycemia in type 2 diabetes: a consensus algorithm for the initiation and adjustment of therapy: a consensus 
statement of the American Diabetes Association and the European Association for the Study of Diabetes. Diabetes Care 2009; 32: 193-203. doi: 10.2337/dc08-9025.

18. Gupta RC, Chang D, Nammi S, Bensoussan A, Bilinski K, Roufogalis BD. Interactions between antidiabetic drugs and herbs: an overview of mechanisms of action and clinical implications. Diabetol Metab Syndr 2017; 9: e59. doi:10.1186/ s13098-017-0254-9

19. Xu X, Shan B, Liao CH, Xie JH, Wen $P$ W, Shi JY. Antidiabetic properties of Momordica charantia L. polysaccharide in alloxan-induced diabetic mice. Int $\mathrm{J}$ Biol Macromol 2015; 81: 538543. doi: 10.1016/j.ijbiomac.2015.08.049

20. Oteng-Amoako AA, Obeng EA. Copaifera salikounda Heckel. Record from PROTA4U. In: Lemmens RHMJ, Louppe D, Oteng-Amoako AA, eds. PROTA (Plant Resources of Tropical Africa / Ressources végétales de l'Afriqutropicale), Wageningen, Netherlands: Wageningen University, 2012. https:// prota4u.org/database/protav8.asp?g=pe\&p=Copaifera + salikounda + Heckel (February, 2021)

21. Aloke C, Ibiam UA, Obasi NA, et al. Effect of ethanol and aqueous extracts of seed pod of Copaifera salikounda (Heckel) on complete Freund's adjuvant induced rheumatoid arthritis in rats. $\mathrm{J}$ Food Biochem 2019; 43(7): e12912. doi: 10.1111/ jfbc. 12912

22. Okwu ED, Ighodaro UB. GC-MS evaluation of bioactive compounds and antibacterial activity of the oil fraction from the leaves of Alstonia boonei De Wild. Pharma Chem 2010; 2(1): 261-2.

23. Lorke D. A new approach to practical acute toxicity tests. Arch Toxicol 1983; 54(4): 275-87.

24. Bell RH, Hye RJ. Animal models of diabetes mellitus: physiology and pathology. J Surg Res 1983; 35: 433-60.

25. Reitman S, Frankel S. A colorimetric method for the determination of serum glutamate oxaloacetate and pyruvate transaminase. Am J Clin Pathol 1957; 28: 56-63. doi:10.1093/ajcp/28.1.56

26. Englehardt VA. Measurement of alkaline phosphatase. Aerztl Labour 1970; 16: 42-3.

27. Weichselbaum TE. An accurate and rapid method for the determination of protein in small amount of blood, serum and plasma. Am J Clin Pathol 1946; 10: 40-9.

28. Doumas BT, Watson WA, Biggs HG. Albumin standard and measurement of albumin with bromcresol green. Clin Chem Acta 1971; 31(1):
$87-96$.

29. Buege JA, Aust SD. Microsomal lipid peroxidation. In: Flesicher S, Packer L, eds. Methods in enzymology. Vol. 52. New York : Academic Press, 1978: 302-10.

30. Fridovich I, Mc-Cord JM. Superoxide dismutase: an enzymatic function for erythrocuperin. J Biol Chem 1969; 244(22): 6045-55.

31. Sinha AK. Colorimetric assay of catalase. Anal Biochem 1972; 47(2): 389-94.

32. Yakubu MT, Akanji MA, Nafiu MO. Antidiabetic activity of aqueous of Cochlospermum planchonii root in alloxan-induced diabetic. Cameroon J Exp Biol 2010; 6: 91-100.

33. Ananda PK, Kumarappan CT, Sunil C, Kalaichelvan VK. Effect of Biophytum sensitivum on streptozotocin and nicotinamideinduced diabetic rats. Asian Pac J Tropical Biomed 2012; 11: 31-5.

34. Alamgeer, Rashid M, Bashir S, et al. Comparative hypoglycemic activity of different extracts of Teucrium stocksianum in diabetic rabbits. Bangladesh J Pharmacol 2013; 8: 186-93.

35. Nagappa AN, Thakurdesai PA, Venkat RN, Singh J. Antidiabetic activity of Terminalia catappa Linn fruits. J Ethnopharmacol 2003; 88: 45-50.

36. Channabasava GM, Chandrappa CP, Sadananda TS. In Vitro antidiabetic activity of three fractions of methanol extracts of Loranthus Micranthus, identification of phytoconstituents by GC-MS and possible mechanism identified by GEMDOCK method. Asian J Biomed Pharm Sci 2014; 4 (34): 34-41.

37. Parker SM, Moore PC, Johnson LM, Poitout V. Palmitate potentiation of glucose-induced insulin release: a study using 2-bromopalmitate. Metabolism 2003; 52 (10): 1367-71.

38. Zuraini A, Zamhuri KF, Yaacob A, et al. In vitro anti-diabetic activities and chemical analysis of polypeptide-k and oil isolated from seeds of $\mathrm{Mo}-$ mordica charantia (Bitter gourd). Molecules 2012; 17(8): 9631-40. doi:10.3390/molecules 17089631

39. World Health Organisation. Diet, nutrition, and the prevention of chronic diseases. World Health OrganisationTechnical Report Series 2003; 916: 1-149.

40. Singh SK, Kesari AN, Gupta RK, Jaiswal D, Watal G. Assessment of antidiabetic potential of Cynodon dactylon extract in streptozotocin diabetic rats. J Ethnopharmacol 2007; 114: 174-9. doi:10.1016/j.jep.2007.07.039

41. Ebong PE, Atangwho IJ, Eyong EU, Egbung GE. The antidiabetic efficacy of combined extracts from two continental plants: Azadirachta indica (A. 
Juss) (Neem) and Vernonia amygdalina Del. (African bitter leaf). Am J Biochem Biotechnol 2008; 4(3): 239-44. doi: 10.3844/ajbbsp.2008.239.244

42. Ezejiofor AN, Okorie A, Orisakwe OE. Hypoglycaemic and tissue-protective effects of the aqueous extract of Persea americana seeds on alloxan-induced albino rats. Malays J Med Sci 2013; 20(5): 31-9.

43. Maniyar Y, Bhixavatimath P. Antihyperglycemic and hypolipidemic activities of aqueous extract of Carica papaya Linn. leaves in alloxan-induced diabetic rats. J Ayurveda Integr Med 2012; 3(2): 70-4. doi: 10.4103/0975-9476.96519

44. Muhtadia M, Primariantia AU, Sujonoa TA. Antidiabetic activity of durian (Durio zibethinus Murr.) and rambutan (Nephelium lappaceum L.) fruit peels in alloxan diabetic rats. Procedia Food Sci 2015; 3: 255-61. doi: 10.1016/j.profoo.2015.01.028

45. Chen PY, Csutora P, Veyna-Burke NA, Marchase RB. Glucose- 6 phos-phate and Ca2+sequestration are mutually enhanced in microsomes from liver, brain, and heart. Diabetes 1998; 4 (6): 874-81. doi:10.2337/diabetes.47.6.874

46. Hakkim FL, Girija S, Kumar RS, Jalaluddeen MD. Effect of aqueous and ethanol extracts of Cassia auriculata L. flowers on diabetes using alloxan - induced diabetic rats. Int J Diabetes Metab 2007; 15: 100-6.

47. Tiwari AK, Rao JM. Diabetes mellitus and multiple therapeutic approaches of phytochemicals: present status and future prospects. Curr Sci 2002; 83: 30-8.

48. Patel DK, Prasad SK, Kumar R, Hemalatha S. An overview on antidiabetic medicinal plants having insulin mimetic property. Asian Pac J Trop
Biomed 2012; 2(4): 320-30. doi: 10.1016/S22211691(12)60032-X.

49. Singh R, Seherawat A, Sharma P. Hypoglycemic, antidiabetic and toxicological evaluation of Momordica dioica fruit extracts in alloxan-induced rats. J Pharmacol Toxicol 2011; 6(5): 454-67. doi: 10.3923/jpt.2011.454.467

50. Saeed MK, Deng Y, Dai R. Attenuation of biochemical parameters in streptozotocin-induced diabetic rats by oral administration of extracts and fractions of Cephalotaxus sinensis. J Clin Biochem Nutr 2008; 42: 21-8. doi: 10.3164/jcbn2008004

51. Mansour HA, Newairy AS, Yousef MI, Sheweita SA. Biochemical study on the effects of some Egyptian herbs in alloxan-induced diabetic rats. Toxicology 2002; 170: 221-8.

52. Kanchana N, Mohamed AS. Hepatoprotective effect of Plumbago zeylanica on paracetamol induced liver toxicity in rats. Int $\mathrm{J}$ Pharm Pharm Sci 2011; 3: 151-4.

53. Afaf A, Faras EI, Elsawaf AL. Hepatoprotective activity of quercetin against paracetamol-induced liver toxicity in rats. Tanta Med J 2017; 45: 92-8. doi: 10.4103/tmj.tmj_43_16

54. Kesavulu MM, Giri R, Kameswara-Rao B, Apparao C. Lipid peroxidation and antioxidant enzyme levels in type 2 diabetics with microvascular complications. Diabetes Metab 2000; 26: 387-92.

55. Qujeq D, Rezvani T. Catalase (antioxidant enzyme) activity in streptozotocin-induced diabetic rats. Int J Diabetes Metab 2007; 15: 22-4.

56. Ceriello A. Oxidative stress and glycaemic regulation. Metabolism 2000; 49(2 suppl 1): 27-9. 


\title{
ANTIDIABETIČNI UČINEK EKSTRAKTA ETANOLA Copaifera salikounda (HECKEL) NA SLADKORNO BOLEZEN, SPROŽENO Z ALLOXAN-OM, PRI PODGANAH
}

\author{
C. Aloke, E. S. Igwe, N. A. Obasi, P. A. Amu, E. C. Ogbonnia
}

Izvleček: Obstaja vedno več dokazov, ki poudarjajo uporabnost zdravilnih rastlin pri zdravljenju različnih bolezni, tudi zaradi različnih negativnih stranskih učinkov, povezanih s konvencionalnimi zdravili. Rastlinske sestavine kot so fenoli in flavonoidi z antioksidativnim potencialom, imajo po nekaterih raziskavah zaščitno vlogo pred degenerativnimi boleznimi, ki jih povzroča oksidativni stres, kot je sladkorna bolezen diabetes mellitus (DM). Študija je bila izvedena z namenom raziskovanja učinka etanolnega semenskega ekstrakta iz rastline Copaifera salikounda (SPEECS) pri podganah s sladkorno boleznijo, ki jo je povzročil alloxan. SPEECS je bil pridobljen z maceracijo praška semen v prahu v absolutnem etanolu 72 ur ter nadaljnjo filtracijo, koncentracijo in sušenjem v vakuumu. Za kvantitativno ugotavljanje kemijskih sestavin SPEECS je bila uporabljena tehnika plinske kromatografije in masne spektrometrije (GC-MS). Štiriindvajset samcev podgan Wistar je bilo naključno razporejenih v štiri skupine ( $n=6)$ : normalna kontrola, kontrola DM, DM + $200 \mathrm{mg} / \mathrm{kg}$ SPEECS in DM + $400 \mathrm{mg} / \mathrm{kg}$ SPEECS. DM je bil pri podganah sprožen z intraperitonealno injekcijo $200 \mathrm{mg} / \mathrm{kg}$ telesne mase alloxana. Po 14 dneh zdravljenja so bile pri različnih skupinah določene spremembe telesne teže in nivo glukoze v krvi (na tešče). Poleg tega so avtorji raziskave izmerili še nekatere serumske biokemične parametre kot so ravni alaninske aminotransferaze (ALT), aspartatne aminotransferaze (AST), alkalne fosfataze (ALP), albumina (ALB), skupnih proteinov (TP), malondialdehida (MDA), superoksiddismutaze (SOD) in katalaze (CAT). Rezultati GC-MS so v izvlečku SPEECS pokazali devet bioaktivnih spojin, v katerih je največ 9-oktadecenojske kisline $(55,75 \%)$. SPEECS (200 in $400 \mathrm{mg} / \mathrm{kg}$ ) je povzročil znatno $(P<0,05)$ povečanje telesne mase, znižanje glukoze $v$ krvi na tešče in znižal raven encimov pokazateljev jetrne funkcije (ALT, AST, ALP), medtem ko je bila raven TP in ALB pri podganah, ki so prejemale SPEECS izrazito povišana v primerjavi z DM kontrolno skupino. Zdravljenje s SPEECS je tudi oslabilo aktivnosti SOD in CAT, medtem ko se je raven MDA znatno zmanjšala $(P<0,05)$ v primerjavi s kontrolno skupino DM. Ta študija je pokazala, da lahko SPEECS ublaži hiperglikemijo pri sladkorni bolezni pri podganah.

Ključne besede: Copaifera salikounda; oksidativni stres; zdravilne rastline; sladkorna bolezen; fitokemikalije; ortodoksni 